\title{
AGAMA DAN MEDIA: PEMAKNAAN ISU AGAMA DI 'DETIKNEWS'
}

\section{Lukas S. Ispandriarno}

Universitas Atma Jaya Yogyakarta

Email: Lukas ispandriarno@yahoo.com

\section{Abstract}

Media has a significant role in strengthening Indonesia's democracy but probiemutic in writing religious issues. More people are respecting media credibility rather than political branch of poner such as parliament, executive or legislative institutions. In the mids of media popularity, it is important io scrutinize online media performance because of its tendency, as well as television media, to focus on selling news for profit. Religious issue bas been written more on its sensationality rather than meaningfully. Seven stories of Detiknews were observed of its title, key words and discussion based on joumalism perspective. The study shows that Detiknews preferred to write sensational titles, immediacy and less accuracy.

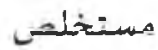

وسانل الإعلام لها دور كبير في تعزيز الديم.قراماية في إندونبسيا ولكن إشكالية في كتابة القضايا الدينية. المزيد

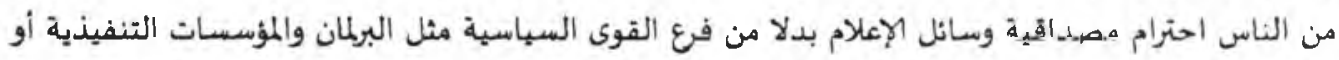

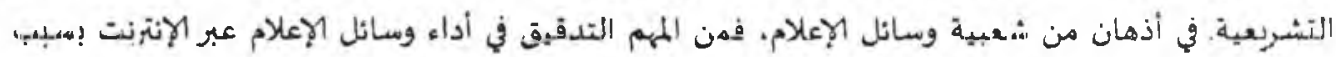

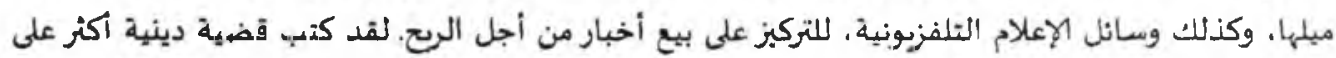

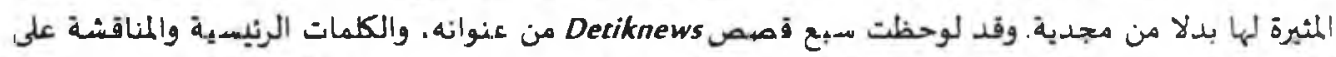
أساس منظور الصحافة. وتبين الدراسة أن Deriknews فضل لكتابة العناوين المثبرة. وأقل دفة الفورية.

Keywords: media, religious issue, online journalism, detiknews.

\section{A.Pendahuluan}

Isu agama menghiasi media massa. "Nasionalisme kita terancam isu agama." Pertanyaannya, apakah isu diberitakan karena memiliki nilai penting (significance) sebagai bagian persoalan bangsa yang harus diselesaikan, ataukah

${ }^{1}$ merdelea.com, 3 Agustus 2012. 
dikabarkan sekadar untuk menarik perhatian khalayak, sebagai barang jualan media?

Media massa dianggap semakin berperan dalam proses demokratisasi pasca Orde Baru. Sejumlah jajak pendapat dan pengamatan mengapresiasi kinerja media karena lebih berperan ketimbang lembaga-lembaga politik seperti legislatif, eksekutif dan yudikatif. Hasil riset Edelman Trust Barometer 2013 menunjukkan tingkat kepercayaan masyarakat terhadap media di Indonesia menduduki salah satu posisi tertinggi di dunia, yaitu 77 persen. ${ }^{2}$ Media menjalankan fungsi sebagai pilar keempat demokrasi (the fourth estate), terutama dalam mengabarkan dan menyoroti merebaknya korupsi yang dilakukan para elite pemegang kekuasaan. Sebagai perbandingan, survai the Reader's Digest 2010 Trusted di Eropa menemukan rata-rata kepercayaan pada pers sebesar 43 persen, di Inggris 23 persen, di Rusia 17 persen dan di Finlandia 68 persen. ${ }^{3}$

Kebebasan bermedia, termasuk pemanfaatan media baru (new media) di Internet, memberi ruang kepada sejumlah kelompok dalam masyarakat, juga kelompok agama. Penyebaran ide, identitas, gagasan semakin terbuka lebar. Jumlah khalayak pengakses media ini jauh lebih besar ketimbang jumlah khalayak media cetak utama (mainstream), suratkabar berlabel nasional. Kemunculan media berbasis agama di era reformasi, yang kebanyakan pers Islam seperti Sabili, Hidayah, Suara Islam, Hidayatullah serta sejumlah situs seperti voice of al-Islam (voa-Islam), eramuslim.com, atau hidayatullah.com didukung jumlah pembaca yang tidak sedikit. Data di Media Planning Guide 2008 menyebut Hidayah sebagai majalah dengan jumlah pembaca terbesar scbanyak 531.000 orang. Sabili pada 2002-2004 bisa menjual 140.000 eksemplar per edisi dengan jumlah pembaca mencapai sekitar satu juta orang. ${ }^{4}$ Reformasi membawa berkah tersendiri bagi pers Islam. ${ }^{5}$

Selain memunculkan kegairahan, kebebasan bermedia menghadirkan scjumlah kekhawatiran karena kepemilikan media, khususnya perusahaan

2ANTARA News, 31 Desember 2012.

3Janet Jones and Lee Salter.. Digital Journalism, (L.ondon: Sage Publication, 2012), hal.57 "sejuk.org, 14 November 2012.

5Subhan Afifi. "Profil Pers Islam di Era Reformasi" dalam Jumal Ilmu Komunikasi Lolume 3, Nomor 3, September-Desember. 2005, hal.313. 
televisi, mengerucut hanya pada beberapa orang sehingga mengancam keberagaman informasi dan ekspresi budaya. ${ }^{6}$ Di tengah proses transisi menuju demokrasi yang terkonsolidasi, media juga mengalami masalah terutama karena dorongan ekonomi untuk tetap bertahan sekaligus mencarj keuntungan. Sejumlah media cetak, elektronik, termasuk online, jatuh ke dalam kecenderungan mengutamakan sensasi agar mendapat perhatian khalayak. Di Jakarta hadir koran Lampu Hijau menyusul "kesuksesan" Lampu Merah, anak perusahaan Jawa Pos. Beberapa kelompok perusahaan besar media menerbitkan koran daerah yang mengusung judul-judul panas, dilengkapi foto, dengan berita singkat. Mereka seolah ingin mengikuti jejak Pos Kota, kuran kuning yang laris dan tetap stabil dengan jumlah pembaca di atas 500 ribu. Berbagai program televisi yang menjual sensasi semacam Silet, digugat penirsa berupa kiriman 1000 SMS ke Komisi Penyiaran Indonesia (KPI) karena mengabarkan Yogyakarta sebagai Kota Malapetaka.Tayangan acara Silet pada 7 November 2010 membawakan materi Gunung Merapi. KPI melaporkan dugaan pelanggaran Undang-Undang Penyiaran Nomor 32 dan pasal 36 ayat 5 tentang isi siaran yang bersifat bohong dan menyesatkan. ${ }^{7}$

\section{B.Media dan Agama}

Biernatzki, dalam artikel berjudul "Mass Media versus Religion?" mengatakan, sepertinya media hanya tertarik pada berita sensasional. Ini berkebalikan dengan agama, yang terlibat secara dalam pada kebenaran langgeng. Inovasi dan sensasionalisme tidak menyuarakan dengan baik kedamaian dan kontemplasi yang berhubungan dengan pengalaman terdalam agama. 8 Berita keagamaan (religious news) dalam media sekuler mengungkap skandal dan konflik yang dari waktu ke waktu membahayakan lembaga-lembaga keagamaan. Bila sebuah agama dalam kesehariannya setia pada tradisi dan

'Puji Rianto, Puji dkkDominari TV Swasta (Nasional) Tergerusnya Keberagaman Isi dan Kepemilikan, (Yogyakarta: PR2Media dan TIFA, 2012).

7 kapanlagi.com, Desember 2012

"E.William Biernatzki, SJ. "Mass Media versus Religion?". Joumal of the Asion Restartb Center for Religion and Social Communication Volume 1 Number 2003. 
menyaksikan "kebijaksanaan langgeng" dengan cepat seperti kehilangan perhatian karena media massa mencari sensasi. Hasilnya, agama direpresentasikan dan diinterpretasikan dengan buruk oleh media. Apakah dihindari atau diberitakan secara sensasional, keduanya mendistorsi kenyataan. ${ }^{9}$ Katanya pula:

And yet, religion tells the greatest and ultimately the most exciting stories that can be told. They are the stories that are most meaningful for buman destiny: the stories that give value to buman beings and to all buman endeavors. Without the religious perspective, nothing the media can say, can be ancbored firmly in reality. The products of the mass media often skirt around the real issues of life - issues that are directly addressed by religion. As a result, those products become essentially unfulfilling and vacwous. Since the media not only mimic life but also provide many of the paradigms on which contemporary people pattern their lives, much of life too, becomes unfulfilling and vacuous for large numbers of people. ${ }^{10}$

Selain menyatakan kehampaan isi berita media, Biernatzki mengritik para komunikator agama, termasuk komunikator Katolik, yang kadang jatuh pada jebakan yang memerangkap komunikator sekuler.

Studi lain menemukan, pemanfaatan media sektarian menjadi faktor penting di Israel karena kemajuan teknologi memungkinkan penyebaran penggunaan media alternatif dan piranti iklan alternatif. Komunikasi alternatif juga dikembangkan karena keterbatasan pemakaian media resmi yang mencegah kelompok sektarian bertindak bebas dan terhambat menemui khalayaknya melalui media utama."

Posisi media sebagai pilar keempat demokrasi berkaitan dengan libertarian theory, yang dipraktikkan pasca reformasi. Teori ini berbanding terbalik dengan otoritarianisme rezim Orde Baru. Libertarian theory mengasumsikan pemerintah hadir untuk melayani individu, dan teori ini percaya bahwa warga negara pada umumnya memiliki hak untuk mendengar semua sisi.

\section{Ibia.}

10lbid.

"Yaron Katz. "Technology Use in the Religious Communities in Israel: Combining Traditional Sociery and Advanced Communications." Joumal of Religion, Media of Digital Cultur ORMDC) Vol 1 Issue 3, 2012. 
dari sebuah isu untuk membedakan kebenaran dari kesalahan. ${ }^{12}$ Teori inilah yang sedang "dinikmati" media di Indonesia, dalam kelemahan dan kelebihannya. Kehadiran Undang-Undang Pers No 40 tahun 1999 menjadi landasan hukum bagi praktik kemerdekaan pers seperti digagas teori libertarian. Dalam pengertian lain, teori ini sejalan dengan filosofi the free marketplace of ideas sebagai realisasi dari kemerdekaan pers. ${ }^{13}$

Dalam perspektif berbeda, media berperan sebagai mediator, memberi ruang bagi semua pandangan atau sektor, berapapun ukuran kelompok atau jumlah pengikutnya. Peran dalam memediasi isu karena persepsi terhadap isu dan orang biasanya ditarik dari media. ${ }^{14}$ Di zaman media, kata Hoover, agama tidak lagi dapat mengendalikan simbolnya. Lanjut Hoover:

"Di masa lalu, pejabat klerikal dapat mendikte di mana, kapan dan bagaimana gagasan agama, simbol, serta pendakuan muncul. Kini, Paus tidak dapat lagi mengendalikan cara Madonna atau Sinead O'Connor menggunakan atau menyalahgunakan simbol agama. Klerik Muslim tidak bisa menghentikan budaya populer memotret Islam dalam cara yang tidak mereka sepakati. Tidak seorangpun dapat mengendalikan apa yang media liput dan bagaimana mereka akan meliputnya. Sinar terang yang bisa ditarik di sekitar agama, melindungi pengawasan sekular, telah lama dipecahkan oleh pengalaman visual yang instan dan universal yang terus meningkat. ${ }^{15}$

\section{C.Kepemilikan Media dan Liputan Agama}

Media memiliki sejumlah masalah dan kecenderungan seperti mengerucutnya kepemilikan yang berakibat pada keseragaman informasi. Kencenderungan ini ditegaskan oleh penelitian Centre for Innovation Policy and Governance (CIPG) yang menyimpulkan bahwa terdapat 12 grup besar

\footnotetext{
12Joseph R.Dominick. Eleventh edition.The Dynamics of Mass Communication Media in Transition,(New York: McGraw-Hill International Edition, 2011).hal.427.

${ }^{13}$ Ibid.hal.431

${ }^{14}$ Denis McQuail. Media Performance: Mass Communication and the Public Interest. London: SAGE, 1992.

${ }^{15}$ Tendai Chari. "Representation of Religion and Religious Issues in Zimbabwean Mass Media" dalam Africana, December, Vol. 4, No.2. 2010, hal.168-9.
} 
menguasai hampir seluruh kanal media di Indonesia. Mereka adalah MNC Media Group, Jawa Pos Group, Kompas Gramedia Group, Mahaka Media Group, Elang Mahkota 'Teknologi, CT Corp, Visi Media Asia, Media Group, MRA Media, Femina Group, Tempo Inti Media dan Beritasatu Media Holding. ${ }^{16}$ Orientasi masing-masing pemilik berpengaruh pada isi media.

Apa yang ditulis, diberitakan atau dikonstruksi media dipengaruhi oleh kehidupan sistem politik di mana media menjadi satu subsistemnya. ${ }^{17}$ Ini bukan berarti media tidak memiliki kekuatan apapun. Media massa mempunyai kekuatan tersendiri dalam memengaruhi sistem politik sehingga relasi keduanya ditandai oleh, pertama, bentuk dan kebijakan politik sebuah negara yang menentukan pola operasi mulai dari kepemilikan, isi, hingga pengawasannya. Kedua, media acapkali menjadi media komunikasi politik para penguasa. ${ }^{18}$ Mengonstruksi realitas artinya menuturkan sebuah peristiwa, keadaan, atau benda di mana media menyusunnya menjadi cerita atau wacana yang bermakna sehingga seluruh isi media tidak lain adalah realitas yang telah dikonstruksi, constructed reality, dengan unsur pengonstruksi utama berupa bahasa. Oleh karena itu pemakaian bahasa tertentu berakibat pada bentuk konstruksi realitas dan makna yang dikandungnya. ${ }^{19}$

Di Indonesia, liputan agama umumnya mewakili sejumlah kecenderungan. Pertama, liputan agama umumnya masih berpusat pada kegiatan ritual dan perayaan keagamaan, institusi keagamaan dan terlebih-lebih peristiwa konflik dengan kekerasan. Kedua, karena cenderung berfokus pada peristiwa konflik, liputan agama biasanya sangat sensasional dan penuh dramatisasi. Ketiga, media masih kerap melakukan labelisasi terhadap kelompok agama atau aliran tertentu. Kecmpat, media juga kurang sering memberi tempat pada kelompok-kelompok minoritas. Jika ada, adalah kelompok minoritas cksklusif yang cenderung menyebarkan kebencian dan kekerasan dan tindakan

16id.yahoo.com, "Peneliti: 12 Grup Media Besar Kuasai Indonesia." http://id.berita.jaboo.com/peneliti-12-grup-media-besar-kuasai-indonesia-151410514.html.

${ }^{17} \mathrm{Ib}$ u Hamad. Konstrulesi Realitas Politik dalam Media Massa Sebuah Studi Critical Discourse Analysis terbadap Berita-berita Politik.,(Jakarta: Granit, 1004).hal.7.

${ }^{18}$ Ibid.hal .7-8.

"Ihid.hal.12-13. 
lainnya yang menarik perhatian media karena sering dianggap punya nilai berita. $^{20}$

Dalam hubungan dengan liputan isu agama, kita patut menyimak hasil Survei The International Journal of Press dan Yayasan Pantau. Menurut survei ini kebanyakan wartawan Indonesia tidak mendukung toleransi beragama. Sebanyak 64,3 persen wartawan mendukung pelarangan Ahmadiyah. Wartawan Indonesia juga relatif mendukung fatwa Majelis Ulama Indonesia yang mengharamkan pluralisme, liberalisme, dan sekularisme. Survei dilakukan terhadap 600 wartawan media cetak/online, televisi, dan radio yang tersebar di 16 provinsi, di antaranya, Aceh, Sumut, DKI Jakarta, Jawa Barat, Bali, dan Sulawesi Utara. Survei menemukan 40,3 persen wartawan menjawab "Indonesia" ketika ditanya identitas diri di atas segala-galanya. Jawaban "muslim" sebanyak 39,7 persen, "wartawan" sebanyak 11,7 persen, dan etnis sebanyak 2,3 persen. $^{21}$

Mengikuti Endy Bayuni, seorang pimpinan media di Jakarta, agama dan media di satu sisi punya kesamaan dalam hal mencari kebenaran. Agama mencari kebenaran, media juga bergerak mencari kebenaran. Bedanya, kalau agama mengklaim dirinya telah menemukan kebenaran, media tidak mengatakan seperti itu. Salah satu disiplin media adalah melakukan cek dan cek ulang serta verifikasi hingga menemukan kebenaran sedekat mungkin. Kebenaran bagi media bersifat relatif. Sementara kebenaran bagi agama bersifat absolut. $^{22}$

\section{D.Detiknews dan Jurnalisme Online}

Kemajuan teknologi informasi dan komunikasi memengaruhi jurnalisme. Penyebaran informasi dan berita tidak lagi menjadi monopoli para jurnalis. Warga biasa pun bisa mengolah dan menyebarkan informasi ke segenap

\footnotetext{
20j.Anto. "Rindu Wajah Damai Agama di Media." Harian Analisa, 7 Oktober, 2011. hatp: / www.analisadaily.com

${ }^{21}$ Ibid.

${ }^{22}$ Khoirul Anam. "Endy M. Bayunj: Kebebasan Media di tengah Konservacisme dan Konflik Agama" dalam http://crcs.ugm,ac.id/interview/34/Endy-M-Bayuni-KebebasanMedia-di-tengah-Konservatisme-dan-Konflik-Agama.html. 2012.
} 
penjuru dunia melalui media sosial, blog, dan beragam bentuk media baru lainnya, dikenal dengan istilah jurnalisme warga (citizen joumalism). Perusahaan media mengantisipasi perkembangan ini dengan menyediakan ruang praktik jurnalisme warga maupun menyelenggarakan media online seperti Detiknews.

Portal media Detiknews menupakan bagian dari Detikcom. Kelahiran Detkcom tak dapat dipisahkan dari dinamika kehidupan media massa di sekitar mundurnya Presiden Soeharto. Nama Detik berasal dari nama majalah De'Tik yang bersama majalah Tempo dan Editor dibredel penguasa tahun 1994 saat Tempo memberitakan tenggelamnya kapal bekas dari Jerman Timur dan dugaan korupsi pembelian kapal tersebut oleh pemerintah. Nama-nama yang tertera sebagai pendiri adalah orang-orang DeTik dan Tempo, seperti Budiono Darsono, mantan wartawan. DeTik, Yayan Sopyan juga mantan wartawan DeTik dan Abdul Rahman, mantan wartawan Tempo. Budiono menjabat Direktur Utama merangkap Wakil Direktur sekaligus Dewan Redaksi.

Detikcom merupakan satu dari sejumlah perusahaan media dalam jaringan (daring) atau online di Indonesia yang mengklaim dirinya terbesar. ${ }^{23}$ Perusahaan ini memiliki 300 pekerja yang mengelola sejumlah portal. Hampir semua portal utama di keluarga Detikcom senantiasa masuk kategori nomor satu di dalam kategorinya. Lima portal utama tersebut adalah detiknews.com, detikhot.com, detiksport.com, detikfinance.com dan detiknet.com. Pada 3 Agustus 2011 CT Corp mengakuisisi Detikcom (P'T Agranet Multicitra Siberkom/Agrakom). Mulai saat irulah secara resmi Detikcom berada di bawah Trans Corp. Chairul Tanjung, pemilik CT Corp membeli detikcom secara total (100 persen) dengan nilai US $\$ 60$ juta atau Rp 521-540 miliar. ${ }^{24}$ Setelah diambilalih, direksi dipegang kalangan Trans Corp - sebagai perpanjangan tangan CT Corp di ranah media. Komisaris Utama dijabat Jenderal (Purn) Bimantoro, mantan Kapolri, yang juga duduk sebagai Komisaris Utama Carrefour Indonesia, milik Chairul Tanjung. ${ }^{25}$

\footnotetext{
${ }^{23}$ about detik. com.

${ }^{24}$ bisnis.com. "Chairul Tanjung buys detik.com." Kamis, 30 Juni 2011. 06:28 WIB, hetp://www.bisnis.com/articles/chairul-taniung-buys-derik-dot-com.

${ }^{25}$ detik.com.
} 
Afifin Asydhad memegang posisi Pemimpin Redaksi detikcom Digital Life, sedangkan Redaktur Pelaksana detiknews diduduki Indra Subagja. ${ }^{26}$ Detiknews juga muncul dalam versi "Harian detik" menyajikan layanan berita berbeda dari www.detik.com investigasi yang mengklaim lebih dalam dan lebih lengkap. "Harian detik" tampil dalam bentuk digital dan dapat dibaca gratis melalui browser atau iPad, terbit dua kali sehari setiap pukul 06:00 WIB dan 16:00 WIB. $^{27}$

Jones dan Salter dalam buku Digital Joumalism (2012) merangkum pandangan sejumlah ahli tentang jurnalisme. Mengikuti Allan, jurnalisme tidak berhubungan dengan teknologi tertentu, tetapi teknologi baru cenderung mengancam praktik jurnalisme. Bagi Michael Schudson, jurnalisme adalah sebuah cara khusus dalam memresentasikan informasi, sedangkan G. Stuart Adams merumuskan praktik jurnalisme sebagai penciptaan atau bentuk ekspresi untuk melaporkan dan berkomentar di media publik atas peristiwa dan ide di sini dan saat ini. Ini merupakan metode utama pembingkaian pengalaman dan pembentukan kesadaran publik atas keadaan kini dan saat ini. Merujuk Bill Kovach dan Tom Rosenstiel yang namanya lebih familir di Indonesia, praktik jurnalisme bertujuan menyediakan informasi komprehensif, independen, reliabel dan akurat. Untuk melakukannya, jurnalis harus berkomitmen pada kebenaran, pada warga negara, pada verifikasi, independen dari mereka yang diliput, dengan tujuan memantau kckuasaan. Ia menyediakan forum bagi kritik publik, menarik dan relevan, komprehensif, proporsional, dan melatih konsiensi personal..$^{28}$

Definisi jurnalisme online termaktub dalam jurnalisme digital. Ini adalah konsep yang sulit untuk mendefinisikannya secara tepat karena dapat menghadirkan makna berbeda bagi orang yang berbeda. Jurnalisme digital merupakan percampuran antara konsep lama dan baru di mana kita mengenal jurnalisme di Barat yang merujuk pada Acta Diurna (peristiwa hariarı), teks resmi tulisan tangan bagi kepentingan umum di Roma zaman Kaisar Julius.

\footnotetext{
${ }^{26}$ dapur.detik.com.

27 detik. news.com.

28Jones and Salter.Ibid.hal.8-10.
} 
Digitisasi (digitization) adalah proses mengubah informasi ke format terbaca di komputer yang lahir di era komputer elektronik abad dua puluh yang mensyaratkan teknologi canggih untuk mendistribusikan dan menayangkannya. Singkatnya, jurnalisme digital adalah penggunaan teknologi digital untuk mencari, menghasiikan dan mengirimkan berita dan informasi kepada khalayak melek komputer yang semakin luas. ${ }^{29}$ James C Foust dalam Online Journalism: Principles and Practices of News for the Web (2005) menyebut tujuh keunggulan jurnalisme online yaitu keleluasaan khalayak untuk mengontrol (audience controh), berita berdiri sendiri atau tidak berurutan (nonlienarity), tersimpan dan mudah diakses kembali (storage and retrieval), ruang lebih luas (unlimited space), segera (immediacy), kemampuan multimedia benupa teks, suara, gambar, video dan komponen lain (multimedia capability), dan interaktif(interactivity).

\section{E.Pemberitaan Isu Agama di Detiknews}

Tulisan ini merupakan studi atas pemberitaan isu agama di situs Detiknews, bagian dari portal Detikcom edisi Desember 2012. Dengan memanfaatkan mesin pencari di Detiknews dan memasukkan kata kunci "isu agama" didapat 888 dokumen. Dari 888 dokumen tersebut Detiknews menempatkan tujuh berita di kelompok dokumen pertama dari puluhan berita yang terbit di bulan yang sama. Teknik ini dipergunakan dengan memanfaatkan watak storage and retrieval media online di mana berita yang dipilih tergolong sebagai berita nasional. Sebagai catatan, selain berita nasional Detiknews juga menurunkan berita internasional dengan sumber berita dari kantor berita atau media asing serta artikel opini.

Sejumlah prinsip dalam jurnalisme dimanfaatkan untuk menganalisis tujuh berita yang didapat yaitu: pertama, analisis berdasarkan enam esensi laporan (berita) yang disebut lengkap yang terdiri: Who, What, When, Where, Why dan How. ${ }^{30}$ Singkatnya, laporan atau berita memuat siapa melakukan apa, kapan, di mana, mengapa dan bagaimana. "Siapa" bisa terdiri dari satu atau

\footnotetext{
${ }^{29}$ Kevin Kawamoto.(ed)..Digital Joumalism Emerging Media and the Changing Horizons of Joumalism (Oxford: Rowman \& Littlefield Publishers, Inc. 2003), hal.4.

${ }^{30}$ Andy Bull.. Multimedia Journalism: a Practical Guide.( Oxon: Routledge, 2010), hal.11.
} 
banyak orang, "apa" adalah kegiatan, peristiwa, kejadian, "kapan" melukiskan waktu terjadinya peristiwa, "di mana" menggambarkan tempat kejadian, "mengapa" berkenaan dengan penyebab terjadinya peristiwa dan bagaimana hal itu terjadi. Kedua, prinsip akurasi (accuracy) sebagai bagian dari pengukuran objektivitas versi Westertahl. ${ }^{31}$ Prinsip akurasi untuk melihat adanya verifikasi data yang berlawanan dengan "realitas" yang dicatat. Misalnya, apakah termasuk ke dalam kesalahan (error) seperti penghilangan (omission), penekanan yang lebih atau kurang, salah ejaan, beadline yang salah, salah kutip, kesalahan umur, nama, tanggal. Di dalamnya terdapat intemal accuracy yaitu kesesuaian antara judul berita dengan isi.

Ketiga, analisis juga dilakukan dengan menyimak penggunaan bahasa dalam kata-kata kunci yang diperkirakan merupakan pengertian "agama." Cara ini dipakai untuk melihat pemahaman Detiknews atas isu agama. Penakaian bahasa tertentu berakibat pada bentuk konstruksi realitas dan makna yang dikandungnya karena bahasa menjadi unsur utama. ${ }^{32}$

Studi juga mencatat judul, edisi atau waktu penerbitan (upload) serta nama lembaga atau individu yang dipilih sebagai narasumber. Dalam media cetak, judul berita cenderung ditulis singkat agar mudah dan cepat dibaca sedangkan narasumber terdiri dari berapa pihak yang mewakili sudut pandang beragam. Dalam dasar-dasar jurnalisme disebutkan bahwa narasumber berita setidaknya berasal dari dua pihak sehingga berita yang ditulis disebut cover boith side atau seimbang (balance). Di Indonesia sejumlah media besar telah menerapkan prinsip multi sisi (multi side) di mana informasi digali dari beberapa (lebih dari dua) narasumber.

Berikut ini judul, edisi, dan narasumber berita yang diamati:

Tabel 1. Judul, Edisi, Narasumber

\begin{tabular}{|l|l|l|l|}
\hline No & Judul & Edisi & Narasumber Lembaga \\
\hline 1 & $\begin{array}{l}\text { Janji Sekadar Janji Pak Bupati } \\
\text { untuk Fany }\end{array}$ & $\begin{array}{l}\text { Senin, 03/12/2012 } \\
08: 39 \mathrm{WIB}\end{array}$ & Individu (Fanny Octora) \\
\hline 2 & Ini Penjelasan Bupat Garut Soal & Selasa, & Eksekutif (Bupati) \\
\hline
\end{tabular}

${ }^{31} \mathrm{McQ}$ uail.loc.cit.

${ }^{32}$ Hamad.Ibid. hal.12-13. 


\begin{tabular}{|l|l|l|l|}
\hline & $\begin{array}{l}\text { Nikah Kilat, Isu Banyak Istri dan } \\
\text { Tuntutan Mundur }\end{array}$ & $\begin{array}{l}\text { 04/12/2012 03:53 } \\
\text { WIB }\end{array}$ & \\
\hline 3 & $\begin{array}{l}\text { Pendemo: Sebagai Rakyat Garut } \\
\text { Kami Malu Atas Tabiat Aceng }\end{array}$ & $\begin{array}{l}\text { Selasa, } \\
04 / 12 / 2012 \quad 13: 42 \\
\text { WIB }\end{array}$ & Eksekutif (Bupat) \\
\hline 4 & $\begin{array}{l}\text { Tak Takut Direshuffle, Menag: } \\
\text { Tak Ada Salahnya Menteri dari }\end{array}$ & $\begin{array}{l}\text { Kamis, } \\
13 / 12 / 2012 \quad 19: 36 \\
\text { WIB }\end{array}$ & Eksekutif (Menteri) \\
\hline 5 & $\begin{array}{l}\text { Jelang Partai } \\
\text { Percaya Diri Dicintai Rakyar \& } \\
\text { Ulama Garut }\end{array}$ & $\begin{array}{l}\text { Senin, 17/12/2012 } \\
15: 43 \text { WIB }\end{array}$ & $\begin{array}{l}\text { Individu } \\
\text { Bupati) }\end{array}$ \\
\hline 6 & $\begin{array}{l}\text { Din Minta BPPOM Intensifkan } \\
\text { Pengawasan Soal Isu Bakso }\end{array}$ & $\begin{array}{l}\text { Rabu, 19/12/2012 } \\
15: 25 \text { WIB }\end{array}$ & Ormas (Muhammadiyah) \\
& Daging Babi & & \\
\hline 7 & $\begin{array}{l}\text { Teror Bom Rakitan Palsu, } \\
\text { Kapolres Minta Warga Samosir }\end{array}$ & $\begin{array}{l}\text { Sabtu, 29/12/2012 } \\
18: 43 \text { WIB }\end{array}$ & Eksekutif (Polisi) \\
& Tenang & \\
\hline
\end{tabular}

Sumber: data diolah.

\section{Judul, narasumber, kelengkapan dan isi berita:}

1.1.Berita nomor 1 berjudul "Janji Sekadar Janji Pak Bupati untuk Fany" terdiri dari tujuh kata, terbit Senin, 03/12/2012. Reporter sebagai penulis berita Deden Gunawan, narasumber Fany Octora. Isi ringkas: Bupati Garut Aceng Fikri ingkar janji. Ia mengirim "SMS talak" kepada Fany Octora. Kutipan pernyataan Fany: "Beliau bilang ingin ada yang menemani umrah, jadi dihalalkan dulu secara agama. Beliau bilang pulang dari umrah mau mengadakan resepsi," kata Fany seperti dikutip majalah Detik, Senin (3/12/2012). Penyataan lainnya: "Saya berpikirnya positif-positif saja. Pengakuan beliau kan sudah nggak mempunyai istri, makanya saya mau," kata Fany.

Berita ini hanya menggunakan satu narasumber sehingga tergolong tidak cover both side atau tidak seimbang. Di dalam teks berita juga tidak disebutkan tempat (where) wawancara sehingga tidak memenuhi unsur kelengkapan $(5 \mathrm{~W}+1 \mathrm{H})$ namun berita ini dapat disebut memiliki internal accuracy, kesesuian antara judul dengan isi berita. 
Dalam memaknai isu agama, berita nomor 1 ini sekadar menceritakan persoalan yang berkaitan dengan agama, menampilkan kata kunci: "agama," "umrah," "MUI," "pesantren Al-Fadlilah."

1.2. Berita nomor 2 berjudul "Ini Penjelasan Bupati Garut Soal Nikah Kilat, Isu Banyak Istri dan Tuntutan Mundur" (13 kata) terbit Selasa, 04/12/2012. Reporter sebagai penulis Oris Riswan Budiana, narasumber tunggal Bupati Garut Aceng HM Fikri. Isi ringkas: alasan Fikri melakukan perceraian. Pernyataan Bupati Garut:

"Ya kan kalau nikah itu harus cocok, harus badan. Jadi antara satu dengan lainnya baik dari sisi hati rasa kan begitu kan ya, sehingga untuk keabadian dari pernikahan itu kan sangat ditentukan oleh kecocokan itu. Ya karena tidak cocok, kemudian takdir daripada bersatu, berpisah, itu bukan otoritas manusia, kita pun harus sadar, mau empat hari, mau sehari, itu pun adalah jangan melupakan bahwa itu takdir dar Allah SWT".

Berita dengan narasumber tunggal tidak memenuhi unsur keberimbangan (balance) dan cover both side merugikan pihak yang diberitakan dan khalayak pembaca. Alasan melakukan perceraian seperti dikemukakan Bupati Aceng merugikan Fanny Octora karena pendapatnya tidak disandingkan. Selain itu penggunaan istilah "kecocokan," "takdir" serta "bukan otoritas manusia" perlu disertai penjelasan baik dari pencetus argumentasi maupun dari ahli perkawinan dalam agama Islam. Lebih jauh lagi alasan "mau empat hari, mau sehar" sebagai sebuah "takdir dari Allah SWT" sungguh memerlukan klarifikasi.

Dalam pemberitaan isu agama seperti ini, media terpercaya melakukan pengecekan dengan. meminta pandangan ahli agama, tetapi Detiknews tidak melakukan langkah ini. Berita nomor 2 ini sepertinya memenuhi internal accuracy namun terdapat kesalahan ejaan (error) penulisan "perwakinan" yang seharusnya "perkawinan." 
Berita ini sekadar menceritakan persoalan yang berkaitan dengan agama dengan sejumlah kata kunci: "nikah siri," "Allah SWT," "Sahabat Rasul," "hadits," "pesantren," "rukun dari pernikahan," "ijab qabul" dan "syari'i .

1.3.Berita nomor 3 berjudul "Pendemo: Sebagai Rakyat Garut Kami Malu Atas Tabiat Aceng" terdiri dari sembilan kata, terbit Selasa, 04/12/2012. Penulis (reporter) Oris Riswan Budiana, narasumber Ketua Penyelamat Masyarakat Garut, Kholis Aksan. Isi ringkas: Bupati Garut Aceng Fikri didesak mundur. Tindakannya menikahi Fany Octora secara siri dan menceraikannya 4 hari kemudian lewat SMS dianggap melecehkan perempuan. Lagi pula alasan cerai hanya karena sang perempuan dianggap tidak perawan. "Sebagai rakyat Garut kami malu, dia santri padahal oknum santri," kata Ketua Penyelamat Masyarakat Garut, Kholis Aksan.

Berita ini tidak memenuhi kelengkapan $(5 \mathrm{~W}+1 \mathrm{H})$ karena tidak mencantumkan keterangan waktu (when) liputan namun tergolong memenuhi internal accuracy. Jumlah narasumber hanya satu alias tidak cover both side. Pemaknaan tentang Agama: sekadar menceritakan persoalan yang berkaitan dengan agama di mana terdapat kata "nikah siri," "santri" dan "tokoh agama."

1.4.Berita nomor 4, judul terdiri dari 10 kata: "Tak Takut Direshuffle, Menag: Tak Ada Salahnya Menteri dari Partai." Terbit hari Kamis, 13/12/2012, reporter Sukma Indah Permana, narasumber tunggal Menteri Agama Suryadharma Ali. Isi ringkas: menanggapi isu reshuffle kabinet Menteri Agama tidak khawatir akan terkena reshuffle dan menyerahkan keputusan pergantian jajaran kabinet ke Presiden SBY. "Itu kan soal yang biasa-biasa saja. Bukan saya yang menilai, tapi presiden," ujar Suryadharma.

Seperti berita lainnya, berita ini hanya memakai satu narasumber, memenuhi kelengkapan berita $(5 \mathrm{~W}+1 \mathrm{H})$ dan ada kesesuaian antara judul dan isi (internal accuracy). Berita ini sekadar menceritakan persoalan yang berkaitan dengan agama. Kata kunci: "Menteri Agama" dan "Ketua Umum PPP" (Partai Persatuan Pembangunan).

1.5.Berita nomor 5 bertajuk "Jelang Paripurna DPRD, Aceng Percaya Diri Dicintai Rakyat \& Ulama Garut" (11 kata), edisi Senin, 17/12/2012, reporter Indra Subagja. Narasumber tunggal pengacara Aceng, Ujang Sujai. Isi 
ringkas: menurut Ujang, Bupati Aceng masih dicintai rakyat, ulama, dan santri di Garut. Oleh karena itu DPRD harus melakukan (sikap) sesuai profesionalitas. Kata Ujang.

"Jadi DPRD harus melakukan sesuai profesionalitas. Pak Aceng itu melakukan nikah siri sesuai perintah agama, dan ini yang lebih tinggi daripada etika. Perintah agama dari Tuhan sedang etika itu buatan manusia."

Berita ini tidak berimbang (cover both side), hanya memuat pernyataan narasumber tunggal Ujang Sujai, pengacara Bupati Garut Aceng Fikri. Lebih dari itu, pernyataannya tidak lengkap, tidak jelas, sama sekali tidak didukung fakta bahwa Aceng memang dicintai rakyat dan ulama Garut. Detiknews bisa meminta pendapat rakyat, ulama atau santri untuk membuktikan klaim itu. Bila tidak ada, pendakuan seperti ini cenderung sebagai pernyataan kosong, tak berdasar. Detiknews semestinya menggali lebih jauh pernyataan Ujang atau meminta pendapat sumber lain. Berita ini lebih merupakan tanggapan atas demo masyarakat Garut. ${ }^{33}$

Pernyataan Ujang lainnya dalam berita ini yang juga memerlukan klarifikasi antara lain: "Pak Aceng itu melakukan rukkah siri sesuai perintah agama, dan ini yang lebih tinggi daripada etika. Perintah agama dari Tuhan sedang etika itu buatan manusia". Kalangan agama (Islam) bisa mengecel: pernyataan seperti ini untuk mendudukkannya pada kebenaran (agama). Pernyataan seperti itu perlu dimintakan pendapat ahli agama sehingga berita ini tidak menimbulkan penafsiran yang keliru di kalangan khalayak atau umat.

Ujang juga memberi peringatan apabila Aceng digulingkan dari kursi bupati. "Pak Aceng punya massa." Kutipan ini bernada ancaman atau ajakan untuk melakukan gerakan massa, prinsip yang seharusnya dihindari oleh media. Pemuatan kutipan ini disebut melanggar etika karena menciptakan disharmoni dalam masyarakat. Selain itu, pernyataan-pertanyaan Ujang, pengacara bupati Garut, juga tidak terbukti. Merujuk liputan berbagai media massa, Aceng bertemu dengan Gubernur Jawa Barat dan menerima surat pemberhentiannya.

${ }^{33}$ Detiknews, 4 Desember 2013. 
"Setelah menerima surat keputusan presiden, Aceng kembali, dan disambut ratusan pendukungnya di Tugu Pertempuran Kubang di ruas jalan Bandung-Garut. Di depan pendukungnya, Aceng meminta maaf karena tak mampu menyelesaikan masa jabatannya secara penuh. Ia bcrharap masyarakat tenang menyikapi kasus ini. ${ }^{34}$

Pemaknaan tentang Agama: di dalam teks terdapat kata-kata kunci yang berkonotasi agama (Islam) seperti: "santri," "nikah siri," perintah "agama."

1.6. Berita nomor 6 berjudul "Din Minta BPPOM Intensifkan Pengawasan Soal Isu Bakso Daging Babi" terdiri dari 10 kata, ditayangkan Rabu, 19/12/2012. Reporter Ahmad Juwari, narasumber Ketua Umum PP Muhammadiyah Din Syamsuddin. Isi ringkas: Din meminta pemerintah lewat Balai Besar Pengawas Obat dan Makanan (BPPOM) lebih mengintensifkan pengawasan soal isu beredarnya daging babi dalam bakso di pasaran. Ia berharap pedagang tidak mencari untung dengan menyengsarakan masyarakat. "Pemerintah yang mengawasi BPPOM. Mengintensifkan pengawasan. Juga terkait lemahnya tempat penjagalan. Segera lembaga pemerintah memeriksa sampel bakso yang beredar," ujar Din.

Bcrita ini memenuhi aspek akurasi internal karena kesesuaian antara judul dengan isi namun dikategorikan tidak cover both side sebab hanya menampilkan Din Syamsuddin sebagai satu-satunya narasumber. Selain itu, meski berita ini tergolong lengkap dan memenuhi aspek akurasi internal namun terdapat kesalahan (error) penulisan nama Din Syamsuddin menjadi Din Syamduddin. Sebuah kesalahan fatal namun barangkali dianggap sepele oleh Detiknews.

Pemaknaan tentang isu Agama: disebut nama Din, Ketua "PP Muhammadiyah" (oranisasi massa keagamaan Islam) dan kata "daging babi" yang diharamkan dalam agama Islam.

1.7. Berita nomor 7 berjudul "Teror Bom Rakitan Palsu, Kapolres Minta Warga Samosir Tenang" terdiri dari sembilan kata. Terbit pada hari Sabtu, 29/12/2012, ditulis oleh Khairul Ikhwan (reporter) dengan nara sumber Kepala Kepolisian Resor (Polres) Samosir, AKBP Donny Damanik. Isi ringkas:

${ }^{34}$ Kompas, 26 Februari 2013. 
Kepolisian masih melakukan penyelidikan untuk mengetahui pelaku yang meletakkan benda mirip bom rakitan di Gereja Katolik St Yoseph di Desa Salaon Toba, Kecamatan Ronggur Nihuta. Beberapa saksi sudah dimintai keterangan. "Kita meminta warga tetap tenang. Kami di sini, bersama unsur Muspida, pemuka masyarakat, dan pemuka agama, sudah melakukan pertemuan dan mengeluarkan pernyataan bersama agar masyarakat tidak resah," kata Kapolres Damanik.

Menyimak judul dan isi beritanya, Detiknews memenuhi unsur akurasi internal namun tidak memenuhi aspek kelengkapan berita $(5 \mathrm{~W}+1 \mathrm{H})$ karena tidak menyertakan keterangan waktu (when). Media hanya mewawancari satu narasumber sehingga dapat dikategorikan tidak cover both side alias tidak berimbang. Pemaknaan isu agama dapat disimak dari kata kunci "Gercja Katolik St Yoseph" dan "pemuka agama."

\section{F.Penulisan judul dan pemaknaan isu agama}

\section{Judul Berita}

Hal paling menonjol dari berita di Detiknews adalah panjangnya judul. Berbeda dengan judul berita di media cetak yang cenderung pendek, sekitar lima kata, Detiknews menyusun judul berita relatif panjang antara 9-11 kata. Menarik pula menyimak penulisan judul berita dengan menggunakan kata "ini" di awal judul, misalnya: Ini Penjelasan Bupati Garut Soai Nikah Kilat, Isu Banyak Istri dan Tuntutan Mundur. Penggunaan kata "ini" menjadi salah satu model atau cara menarik perhatian pembaca di media online termasuk Detiknews. Kata "ini" seolah menuntun atau mengarahkan (directive), menggiring pembaca untuk memilih dan membacanya.

Dari tujuh judul berita, terlihat kecenderungan pilihan kata (diksi) mengarah pada sensasionalisme. Sensasi artinya mengutamakan kepuasan perasaan, vulgar, mencengangkan, wah, heboh. Misalnya "Janji tinggal janji bupati," "Nikah kilat, banyak istri," "Menag tak takut direshuffle," "Aceng dicintai rakyat," "Bakso daging babi," "Teror bom rakitan." Judul berita sensasional banyak dipakai media kuning (yellow joumalism) yang mengutamakan isu seks, kriminalitas, gosip di kalangan selebriti. Media Detiknews 
mendekatkan isu agama dengan isu sensasional atau cenderung menyamakan isu agama dengan isu sensasional.

\section{Pemaknaan isu agama}

Dari tujuh berita yang diteliti diperoleh sejumlah kata kunci yang menggambarkan makna agama sebagai berikut:

\section{Tabel 2. Judul, Kata kunci, Identitas narasumber}

\begin{tabular}{|c|c|c|c|}
\hline No & Judul & Kata kunci & Identitas narasumber \\
\hline 1 & $\begin{array}{l}\text { Janji Sekadar Janji Pak } \\
\text { Bupati untuk Fany }\end{array}$ & $\begin{array}{l}\text { agama, umrah, MUI, } \\
\text { pesantren Al-Fadlilah. }\end{array}$ & Fany Octora, Istri Aceng \\
\hline 2 & $\begin{array}{l}\text { Ini Penjelasan Bupati } \\
\text { Garut Soal Nikah Kilat, } \\
\text { Isu Banyak Istri dan } \\
\text { Tuntutan Mundur }\end{array}$ & $\begin{array}{l}\text { nikah siri, Allah SWT, } \\
\text { Sahabat Rasul, hadits, } \\
\text { pesantren, rukun } \\
\text { pernikahan, ijab qabul, } \\
\text { syar' }\end{array}$ & Aceng Fikri, Bupati Garut \\
\hline 3 & $\begin{array}{l}\text { Pendemo: Sebagai Rakyat } \\
\text { Garut Kami Malu Atas } \\
\text { Tabiat Aceng }\end{array}$ & $\begin{array}{l}\text { nikah siri, santri, tokoh } \\
\text { agama. }\end{array}$ & $\begin{array}{l}\text { Kholis Aksan, Koordinator } \\
\text { demo }\end{array}$ \\
\hline 4 & $\begin{array}{l}\text { Tak Takut Direshuffle, } \\
\text { Menag: Tak Ada Salahnya } \\
\text { Menteri dari Partai }\end{array}$ & $\begin{array}{l}\text { Menteri Agama, Partai } \\
\text { Persatuan } \\
\text { Pembangunan }\end{array}$ & $\begin{array}{l}\text { Suryadarma Ali, Menteri } \\
\text { Agama }\end{array}$ \\
\hline 5 & $\begin{array}{l}\text { Jelang Paripurna DPRD, } \\
\text { Aceng Percaya Diri } \\
\text { Dicintai Rakyat \& Ulama } \\
\text { Garut }\end{array}$ & $\begin{array}{l}\text { santri, nikah siri, } \\
\text { perintah agama. }\end{array}$ & $\begin{array}{l}\text { Ujang Sujai, Pengacara } \\
\text { Bupati Garut }\end{array}$ \\
\hline 6 & $\begin{array}{l}\text { Din Minta BPPOM } \\
\text { Intensifkan Pengawasan } \\
\text { Soal Isu Bakso Daging } \\
\text { Babi }\end{array}$ & $\begin{array}{l}\text { Muhammadiyah, } \\
\text { daging babi }\end{array}$ & $\begin{array}{l}\text { Din Syamsuddin, Ketua } \\
\text { PP Muhammadiyah }\end{array}$ \\
\hline 7 & $\begin{array}{l}\text { Teror Bom Rakitan Palsu, } \\
\text { Kapolres Minta Warga } \\
\text { Samosir Tenang }\end{array}$ & $\begin{array}{l}\text { Gereja katolik, pemuka } \\
\text { agama }\end{array}$ & $\begin{array}{l}\text { Donny Damanik, Kapolres } \\
\text { Samosir }\end{array}$ \\
\hline
\end{tabular}

Sumber: data diolah.

Kata-kata kunci yang dipakai Detiknews seperti tertera dalam tabel 2 berasal dari tiga kelompok berita. Pertama kelompok berita tentang pernikahan Bupati Aceng HM Fikri dengan Fany Octora, kedua berita tentang Menteri Agama Suryadharma Ali, dan ketiga berita tentang teror bom di gereja katolik Samosir. Sebagian besar kata kunci merupakan istilah yang ada dalam agama 
Islam dan satu istilah dalam agama Katolik. Detiknews tidak mengurai atau menjelaskan lebih jauh makna kata-kata kunci tersebut.

Kajian ini mendapati, pemberitaan isu agama lebih berfokus pada skandal dan konflik yang terjadi di elite kekuasaan seperti diingatkan Biernatzki. Pemberitaan model ini di satu sisi dapat dianggap sebagai upaya mengontrol kekuasaan (the fourth estate), terutama kekuasaan Bupati Garut Aceng Fikri, namun pada sisi yang lain, berita-berita semacam ini lebih mengarah kepada penjualan isu skandal pejabat publik, isu yang berkaitan dengan perkawinan, seks. Media belum menjalankan peran sebagai ruang informasi komprehensif, melalui verifikasi, berwatak independen seperti dikemukakan Jones dan Salter. Media cenderung digerakkan oleh semangat bisnis, supaya laku dibaca. Dalam pemberitaan tentang perkawinan Aceng Fikri dengan Fany Octora sama sckali tidak ada pendapat dari ahli agama Islam yang tentu akan sangat bermanfaat mendudukkan pada perkara agama yang sebenarnya.

Dari aspek jurnalisme, Detiknews menerapkan sejumlah prinsip dalam jurnalisme online seperti berita sendirian atau tidak berurutan (nonlienarity) di mana semua beritanya hanya memakai satu narasumber, narasumber lain ditulis di berita tersendiri. Media ini juga lebih mengejar kesegeraan (immediacy) dan sedikit melupakan akurasi serta kelengkapan berita. Wawancara tertentu, misalnya dengan Aceng Fikri ataupun Fany Octora diberi tempat yang luas karena memanfaatkan keluasan ruangan (unlimited space). Seperti kebanyakan media daring lainnya, Detiknews juga tidak memanfaatkan kemampuan multimedia (multi media capability) antara lain pemanfaatan gambar, suara, video dan komponen lain. Hanya dua komponen yang dipergunakan yaitu teks dan foto itupun menggunakan satu foto untuk beberapa berita. Watak interaktif (interactivity) diterapkan dalam penyediaan ruang komentar.

\section{G.Penutup}

Media massa dan khususnya media daring memiliki peran memajukan demokrasi, termasuk di dalamnya memberikan pemaknaan yang benar terhadap isu agama. Kecenderungan perusahaan media dalam mengutamakan keuntungan ekonomi mendorong para awak media, jurnalis atau redaktur 
menempatkan isu agama sebagai komoditi. Akibatnya, isu agama disamakan dan ditempatkan sebagai isu sensasional melalui judul-judul yang ditampilkan. Lebih dari itu, tidak ada upaya memaknai isu-isu tersebut secara mendalam, setidaknya secara proporsional sebagai sebuah masalah agama yang berhubungan dengan keagungan Tuhan.

Sejumlah istilah yang berkaitan dengan agama Islam maupun Katolik dalam beberapa berita tidak dimintakan penjelasan dari ahli agama yang memang berkompeten sehingga mengaburkan makna hakikinya. Dari pcrspektif jurnalistik, Detiknews lebih mengejar kesegeraan (immediacy) dan sedikit mengabajkan akurasi serta kelengkapan berita. Berbagai kemampuan multirnedia jurnalisme online juga belum dimanfaatkan media daring dalam mengabarkan isu-isu agama yang menjadi fokus penelitian ini.

\section{DAFTAR PUSTAKA}

Afifi, Subhan,2005. "Profil Pers Islam di Era Reformasi" dalam Jumal Ilmu Komunikasi Volume 3, Nomor 3, September-Desember, hal.313-338.

AntaraNews.2013. "Riset: tingkat kepercayaan pada media di Indonesia tinggi" Kamis, 31 Januari 2013 22:25 WIB http://www.antaranews.com. diakses 20/2/2013.

Anto, J. 2011. "Rindu Wajah Damai Agama di Media." Harian' Analisa, 7 Oktober. http://www.analisadaily.com

Anam, Khoirul. 2012. "Endy M. Bayuni: Kebebasan Media di tengah Konservatisme dan Konflik Agama" dalam http://crcs.ugm.ac.id/interview/34/Endy-M-Bayuni-KebebasanMedia-di-tengah-Konservatisme-dan-Konflik-Agama.html

Biernatzki, SJ, William E.2003. "Mass Media versus Religion?". Joumal of the Asian Research Center for Religion and Social Communication Volume 1 Number 2003.

bisnis.com. 2011. "Chairul Tanjung buys detik.com." Kamis, 30 Juni. 06:28 WIB, http://www.bisnis.com/articles/chairul-taniung-buys-detik-dotcom, diakses 23/2/2013.

Bull, Andy. 2010. Multimedia Journalism: a Practical Guide. Oxon: Routledge. 
Chari, Tendai. 2010. "Representation of Religion and Religious Issues in Zimbabwean Mass Media" dalam Africana, December, Vol. 4, No.2, hal.165-190.

Detiknews, Senin, 03/12/2012 08:39 WIB. "Janji Sekadar Janji Pak Bupati untuk Fany," detik.com/search?query=Janji + Sekadar + Janji + Pak + Bupati + untuk $+F$ any\&sortby $=$ time \&sortime $=0 \&$ siteid $=3 \&$ location $=\&$ fromdate $=\&$ tu datex $=$, diakses $22 / 2 / 2013$

Detiknews, Selasa, 04/12/2012 03:53 WIB. "Ini Penjelasan Bupati Garut Scal Nikah Kilat," Isu Banyak Istri dan Tuntutan Mundur, detik.com/index.php?query =Ini+Penjelasan + Bupati+Garut + Soal $+\mathrm{Ni}$ $\mathrm{kah}+\mathrm{Kilat} \% 2 \mathrm{C}+\mathrm{Isu}++$ Banyak + Istri + dan + Tuntutan + Mundur\&siteid $=3 \& \mathrm{fa}=$ detik.search, diakses 22 Februari 2013.

Detiknews, Selasa, 04/12/2012 13:42 WIB. "Pendemo: Sebagai Rakyat Garut Kami Malu Atas Tabiat Aceng," http://news.detik.com/read/2012/12/04/134205/2108944/10/pcnd emo-sebagai-rakyat-garut-kami-malu-atas-tabiat-aceng. diakses, 22/2/2013.

Detiknews, Kamis, 13/12/2012 19:36 WIB. "Tak Takut Direshuffle, Menag: Tak Ada Salahnya Menteri dari Partai," http://news.detik.com/read/2012/12/13/193626/2118080/10/taktakut-direshuffle-menag-tak-ada-salahnya-menteri-dari-partai, diakses $22 / 2 / 2013$.

Detiknews, Senin, 17/12/2012 15:43 WIB. "Jelang Paripurna DPRD, Aceng Percaya Diri Dicintai Rakyat \& Ulama Garut," http://search.detik.com/index.php?query=Jelang+Paripurna+DPRD $\% 2 \mathrm{C}+$ Aceng + Percaya + Diri+Dicintai ++ Rakyat $+\% 26+$ Ulama + Garut \&siteid $=3 \& \mathrm{fa}=$ detik. search, diakses $22 / 2 / 2013$.

Detiknews, Rabu, 19/12/2012 15:25 WIB. Din Minta BPPOM Intensifkan Pengawasan Soal Isu Bakso Daging Babi, http://news.detik.com/read/2012/12/19/152507/2122524/10/din- 
minta-bppom-intensifkan-pengawasan-soal-isu-bakso-daging-babi, diakses 22/2/2013.

Detiknews, Sabtu, 29/12/2012 18:43 WIB. Teror Bom Rakitan Palsu, Kapolres Minta Warga Samosir Tenang, http://news.detik.com/read/2012/12/29/184338/2129569/10/teror -bom-rakitan-palsu-kapolres-minta-warga-samosir-tenang, diakses $22 / 2 / 2013$.

Dominick, Joseph R. 2011. Eleventh edition. The Dynamics of Mass Communication Media in Transition.New York: McGraw-Hill International Edition.

Foust, James C. 2005. Oniine Journalism: Principles and Practices of News for the

W'eb. Scottsdale: Holcomb Hathaway, Publishers.

Hamad, Ibnu. 1004. Konstruksi Realitas Politik dalam Media Massa Sebuab Studi Critical Discourse Analysis terhadap Berita-berita Politik. Jakarta: Granit.

id.berita.yahoo.com. "Peneliti: 12 Grup Media Besar Kuasai Indonesia." http://id.berita.yahoo,com/peneliti-12-grup-media-besar-kuasaiindonesia-151410514.html, diakses 22/2/2013.

Islahudin.2012. "Nasionalisme kita terancam isu agama." Merdeka, 3 Agustus. http://www.merdeka.com/khas/nasionalisme-kita-terancam-isuagrama-wawancara-jalaluddin-r-3.html, diakses 21/2/2013.

Jones, Janet dan Salter, Lee. 2012. Digital Joumalism. London: Sage Publication. kapanlagi.com.2010. "KPI Laporkan Tayangan 'SILET' ke Polri." http://www.kapanlagi.com/showbiz/televisi/kpi-laporkan-tayangan-

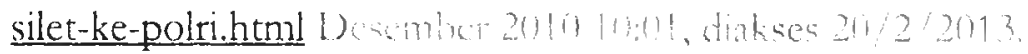

Kawamoto, Kevin (ed). 2003.Digital Joumalism Emerging Media and the Changing Horizons of Joumalism. Oxford: Rowman \& Littlefield Publishers, Inc.

Katz, Yaron. 2012. "Technology Use in the Religious Communities in Istael: Combining Traditional Society and Advanced Communications." Joumal of Religion, Media of Digital Culture (JRMD) Vol 1 Issue 3.

McQuail, Denis. 1992. Media Performance: Mass Communication and the Public Interest. London: SAGE.

Rianto, Puji dkk. 2012. Dominasi TV Swasta (Nasional) Tergerusnya Keberagaman Isi dan Kepemilikan. Yogyakarta: PR2Media dan TIFA. 